Mavor, G E. (1956). J. Bone Jt. Surg., 38B, 513.

Miller, H., and Wilson, G. M. (1951). Brit. Heart J., 13, 227.

Pearson, C., Adams, R. D., and Denny-Brown, D. (1948). New Engl $j$. Med.. 239. 213 .

Perkins, G. (1901). Orthopaedics, p. 926. Athlone Press, London.

Wells, H. S., Youmans, J. B., and Miller, D. G. (1938). J. clin. Invest., 17, 489.

\section{TREATMENT OF MACROGLOBULINAEMIA}

BY

\author{
N. CONWAY, M.B., M.R.C.P. \\ Senior Howse Officer, Whittington Hospital, London
}

AND

J. MILES WALKER, M.B., M.R.C.P., M.R.C.P.Ed. Senior Medical Registrar, Whittington Hospital, London

Macroglobulinaemia was first described by Waldenström in 1944 . It is characterized by an abnormal tendency to bleed, anaemia, and an increased liability to intercurrent infections ; cardiac failure may complicate the clinical picture. Hepatosplenomegaly and generalized lymphadenopathy are frequent, and various neurological lesions (Logothetis et al., 1960) and an unusual retinopathy (Coyle et al., 1961) are described.

The spleen, lymph nodes, and marrow are infiltrated by lymphocytoid cells and plasma cells (Zollinger, 1958), and Curtain and O'Dea (1959) have shown that the abnormal macroglobulins are produced by the latter. Recently, chromosomal abnormalities have been reported (Bottura et al., 1961).

Macroglobulinaemia may occur in association with other diseases, such as multiple myelomatosis, lymphosarcoma, and leukaemia, but in many cases no such association is demonstrable. The course of the disease varies in severity and spontaneous remissions may occur. As normal human plasma contains small amounts of macroglobulins, an important diagnostic criterion is the demonstration by ultracentrifuge studies that they constitute at least $10 \%$ of the plasma proteins (Martin, 1960).

We report a case treated by plasmapheresis (the selective removal of plasma).

\section{Case Report}

A man aged 55 was admitted to hospital on March 6, 1961, complaining of lassitude, dizziness. ankle-swelling, palpitations, and breathlessness on exertion of three months' duration. Seven weeks previously, prolonged bleeding had followed dental extraction and for two weeks he had noticed blurred vision and deafness.

On examination he was anaemic and breathless, and had slight ankle oedema; the gum margins were bleeding. The liver was palpable $5 \mathrm{~cm}$. below the costal margin, but there was neither splenomegaly nor lymphadenopathy. His deafness consisted in a conduction defect on the left (with a scarred tympanic membrane) and a nerve deafness on the right (confirmed by audiometry). The fundi showed gross papilloedema and venous engorgement with numerous retinal haemorrhages but no exudates or arterial changes. The central nervous system was otherwise normal, as were the respiratory and cardiovascular systems.

\section{Investigations}

Haemoglobin, $44 \%$ (6.5 g./100 ml.); white-cell count, $5,300 /$ c.mm. (polymorphs $75 \%$, lymphocytes $21 \%$, mono- cytes $3 \%$, eosinophils $1 \%$ ); E.S.R., $144 . \mathrm{mm} . /$ hour (Westergren) ; reticulocytes, $1 \%$; platelets, 102.000/c.mm. ; bleeding-time, over 37 minutes : clotting-time. 8 minutes 20 seconds (Lee and White). One-stage prothrombin time, normal; prothrombin concentration, 64\%; two-stage prothrombin value, $90 \%$ of normal ; Stuart-Prower assay, $76 \%$ (a low value probably due to the effect of the abnormal proteins on the incomplete thromboplastin "stypven" used) ; factor VII assay, $90 \%$; thrombin/fibrinogen reaction, normal ; plasma fibrinogen. $0.33 \mathrm{~g} .1100 \mathrm{ml}$. Thromboplastin generation test showed an inhibitor effect on the formation of intrinsic thromboplastin. Urine, no protein or Bence Jones protein; blood urea, $72 \mathrm{mg} . / 100 \mathrm{ml}$. ; liver-function tests, normal: plasma proteins, $10.3 \mathrm{~g} . / 100 \mathrm{ml}$, electrophoresis showing a large amount of an abnormal protein between the beta and gamma positions with reduction of the gamma globulin and increase of the alphaz-globulin; Sia test, positive; bone-marrow, hypoplastic with an increase in lymphoid cells but no myeloma cells and no evidence of leukaemia. $X$-ray examination of the chest, skull, and dorso-lumbar spine, normal; barium-meal examination, normal. Chromosomes normal in number and morphology. Ultracentrifuge studies of the plasma proteins confirmed the diagnosis.

\section{Progress}

On the day after admission he had a haematemesis. After the transfusion of 9 pints $(5.1$ litres) of blood over the next three days his haemoglobin was $57 \%(8.4 \mathrm{~g} . / 100 \mathrm{ml}$.) but no further manifest bleeding had occurred. Renewed bleeding from the gums preceded another large haematemesis on April 26 and additional transfusion was required. On May 4 he developed suppurative parotitis with rapidly spreading cellulitis of the neck and upper chest ; this responded eventually to incision and antibiotics.

Plasmapheresis was begun on May 30, 42 units of plasma being removed in four weeks (a unit being defined in this article as that quantity of citrated plasma discarded from each pint bottle of venesected blood, and averaging $400 \mathrm{ml}$.). Improvement was rapid, with increased well-being. return of appetite, cessation of bleeding from the gums. lessening of dyspnoea, improvement in vision and hearing. and regression of the retinal changes. The plasma proteins, initially $9 \mathrm{~g} . / 100 \mathrm{ml}$. (albumin $2.6 \mathrm{~g}$., globulin $6.4 \mathrm{~g}$.) were lowered to $6.8 \mathrm{~g} . / 100 \mathrm{ml}$. (albumin $2.4 \mathrm{~g}$., globulin $4.4 \mathrm{~g}$.).

He was discharged on July 22 , but renewed symptoms necessitated readmission on August 8, examination revealing a striking deterioration in the retinopathy with many new haemorrhages. The haemoglobin was $38 \%(5.6 \mathrm{~g} / 100 \mathrm{ml}$.) and the plasma proteins were $9.2 \mathrm{~g} . / 100 \mathrm{ml}$. (albumin $2.3 \mathrm{~g}$., globulin 6.9 g.). Transfusion was necessary. and this obscured the results of the subsequent plasmapheresis of 16 units of plasma in five days. Once more marked symptomatic improvement occurred, with regression of the retinal changes. On discharge penicillamine, $300 \mathrm{mg}$. t.d.s., was started, and was continued for the rest of his life.

A third admission was arranged for September 15. when the plasma proteins were $10.8 \mathrm{~g} . / 100 \mathrm{ml}$. and symptoms had just reappeared. Removal of 18 units of plasma over three days produced improvement uniform with that previously seen.

His final admission, on October 11, was with bronchopneumonia of two days' duration. His condition was peror, the haemoglobin being $43 \%(6.4 \mathrm{~g} . / 100 \mathrm{ml}$. and the whitecell count $2.000 /$ c.mm. (lymphocytes $99 \%$, polymorphs $1 \%$ ). Blood cultures grew Escherichia coli profusely, and despite energetic antibiotic treatment he died on October 13, 1961.

Post-mortem Findings.-The significant findings were bronchopneumonia. a large spleen $(720 \mathrm{~g}$.$) , and enlargement$ of the cervical lymph nodes only. The brain was normal. Histologically there was infiltration by lymphocytes and plasma cells of the spleen, lymph nodes, kidneys, portal tracts of the liver, and bone-marrow, which, additionally, showed hyperplasia of all elements, numerous granulocyte precursors, and no evidence of maturation arrest. 


\section{Method of Plasmapheresis}

Blood was taken in the usual manner into $3.8 \%$ citrate, the bottle then being inverted. The high sedimentation rate of this patient's blood (never below $140 \mathrm{~mm}$./hour) produced virtualky complete separation of cells and plasma in one hour. With careful insertion of the needle of a plastic giving set, the red-cell layer was transfused back into the patient, disturbance of the cells being avoided by the use of a long needle reaching above the plasma level as an air inlet. The transfusion was stopped once the layer of cells had been given, the end-point being well defined. Venesection of 2 pints $(1,140 \mathrm{ml}$.) of blood at a time caused no distress and, later, this procedure was well tolerated on two, and eventually three, occasions daily for up to three days.

\section{Discussion}

The bleeding tendency in macroglobulinaemia has been attributed to interference with platelet function by circulating macroglobulins (Pachter et al., 1959), and our haematological findings support this view. Increased plasma viscosity (due to the high molecular weight of the abnormal proteins) is the probable cause of the retinopathy (Martin, 1960) and, together with anaemia, may cause cardiac failure.

Clearly, treatment aimed at a reduction of the level of circulating macroglobulins should favourably affect both the haemorrhagic tendency and the effects of raised plasma viscosity. This could theoretically be accomplished, firstly, by an attack on the cells which have been shown to elaborate the abnormal proteins; secondly, by an attempt to modify the macroglobulins already formed; or thirdly, by their repeated removal by plasmapheresis or exchange transfusion.

The first approach, using cytotoxic agents or corticosteroids, has with few exceptions proved ineffective. Depolymerization of macroglobulins (with resultant reduction of plasma viscosity) is produced in vitro by penicillamine $(\beta \beta$ dimethyl cysteine) (Deutsch and Morton, 1957), and Glenchur et al. (1958) report a significant fall of viscosity in one case treated with this drug but not in another. Its administration in our case had no apparent effect.

The third possibility was first explored by Schwab and Fahey (1960), who successfully treated two cases of macroglobulinaemia by venesecting blood, centrifuging it, removing the supernatant plasma, and transfusing the red cells, resuspended in saline, back into the patient. Our method, utilizing the patient's persistently high E.S.R., required only simple equipment and minimized contamination.

Plasmapheresis consistently produced improvement, albeit temporary, and was notably successful in controlling the bleeding tendency. Our aim was to keep the patient alive by maintaining a relatively small reduction in circulating macroglobulins in the hope that a natural remission might occur, and it is interesting that Schwab and Fahey were able to discontinue the procedure in one patient.

Plasmapheresis has been studied largely in dogs (Whipple, 1938 ; Elman et al., 1943), which are difficult to deplete of protein in this way. In man, limited experiments showed no apparent alteration in antibody formation (Smolens et al., 1957), and Schwab and Fahey (1960) removed 62 units of plasma in 51 days from one case (final total, 230 units in 12 months) and 48 units in 30 days from another without ill effect. Clearly, however, normal plasma constituents, especially proteins, are removed, and although in our case the level of albumin remained constant, it is conceivable that normal globulins (particularly gamma-globulin) were depleted significantly, and since the liability to intercurrent infection in macroglobulinaemia is attributed to impaired antibody formation (Mackay et al., 1956), it is suggested that plasmapheresis should be reserved for rapidly progressive cases, particularly when, as in our case, haemorrhage is a prominent feature.

The terminal agranulocytosis is difficult to reconcile with the hyperplastic marrow at post-mortem examination and, furthermore, its cause is uncertain. Plasmapheresis, last performed three weeks before death, never significantly affected the white-cell count. The overwhelming infection possibly explains the finding, or perhaps, with leucopenia as a reported feature of some cases of macroglobulinaemia, it may have represented a manifestation of the disease itself. Lastly, the agranulocytosis may have been a hitherto unreported toxic effect of penicillamine.

\section{Summary}

A case of Waldenström's macroglobulinaemia is reported which showed a rapidly progressive course. The principal clinical features were severe anaemia, bleeding from mucous membranes, a characteristic retinopathy, and a tendency to develop intercurrent infections.

Consideration of the pathology of this syndrome suggested that reduction of the amount of macroglobulins in the plasma would produce symptomatic relief, and methods of effecting such a reduction are discussed. In the case reported this was accomplished by the selective removal of plasma (plasmapheresis) by a simple method, and consistent though temporary improvement resulted. The disadvantages of plasmapheresis are discussed and it is concluded that, as the possibility of remission exists, this procedure may be a worth-while form of palliative therapy in rapidly progressive cases, especially those in which bleeding is troublesome.

We wish to thank Dr. A. L. Jacobs for permission to publish the case; Dr. P. B. Booth, of the North London Blood Transfusion Centre, for his interest and help; Dr. S. H. G. Robinson, Miss M. F. Crowley, and the staff of the Department of Pathology, Whittington Hospital, for the investigations and post-mortem findings; Dr. Court Brown for the chromosome count; Mr. K. W. Denson for the detailed coagulation studies; and Dr. S. Griffiths for studies of protein formation.

\section{REFERENCES}

Bottura, C., Ferrari, I., and Veiga, A. A. (1961). Lancet, 1, 1170 .

Coyle, J. J., Frank, P. E., Leonard, A. L., and Weiner, A. (1961) Arch. Ophthal., 65, 75.

Curtain, C. C., and O'Dea, J. F. (1959). Aust. Ann. Med., 8, 143 .

Deutsch, H. F., and Morton, J. L. (1957). Science, 125, 600.

Elman, R., Charnas, R., and Davey, H. W. (1943). Arch. Surg. 47, 216.

Glenchur, H., Zinneman, H. H., and Briggs, D. R. (1958). Ann. intern. Med., 48, 1055

Logothetis, J., Silverstein, P., and Coe, J. (1960). Arch. Neurol. (Chic.), 3, 564.

Mackay, I. R., Eriksen, N., Motulsky, A. G., and Volwiler, W. (1956). Amer. J. Med.. 20, 564.

Martin, N. H. (1960). Quart. J. Med., 29, 179

Pachter, M. R., Johnson, S. A., Neblett, T. R., and Truant, J. P (1959). Amer. J. clin. Path. 31, 467.

Schwab, P. J., and Fahey, J. L. (1960). New Engl. J. Med. $263,574$.

Smolens, J., Stokes, J., and Vogt, A. B. (1957). J. Immunol., 79, 434

Waldenström, J. (1944). Acta med. scand., 117, 216.

Whipple, G. H. (1938). Amer. J. med. Sci., 196, 609.

Zollinger, H. U. (1958). Helv. med. Acta, 25, 153. 